\title{
クアゼパムの吸収過程における食事摂取時間と 食事中の脂肪量の影響について
}

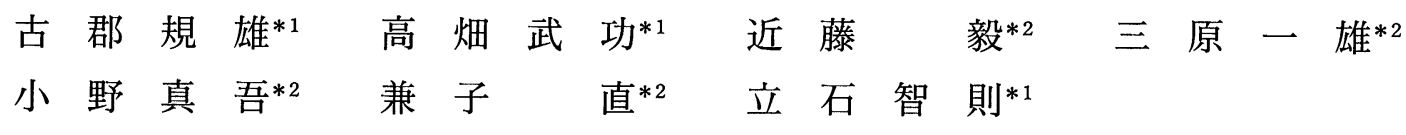

\begin{abstract}
【緒言】
クアゼパムは長時間作用型のベンゾジアゼピン 系睡眠薬である。クアゼパムは投与量に比例し その効果が増強することから、クアゼパムやそ の代謝物の血漿濃度に薬効が関連することが予 測される。よって、血漿濃度に影響を与える要 因の検討は臨床的に重要である。

本邦の比較的少人数 ( $\mathrm{n}=6$ vs $\mathrm{n}=6)$ により施行さ れた第一相試験において、クワゼパムの最高血 漿濃度が絶食時に比較して、高脂肪食との併用 により約 3 倍に増加したことから、クアゼパム と食事との併用は禁忌となっている。

従って、本研究はクアゼパムの単回経口投与後 の薬物動態および薬力学における食事の影響を、 食事摂取時間と食事中の脂肪含量に焦点をあて、 検討した。
\end{abstract}

\section{【方法】}

本研究に対し文書で同意の得られた 9 名の健常 男性（22〜44 歳）を対象に、2 週間の休薬期間 を置いた以下に示した 4 種類の条件を無作為化 クロスオーバー法にて $20 \mathrm{mg}$ のクアゼパムを単 回経口投与した。

A) 12 時間以上の絶食後

B）低脂肪食（トースト 2 枚・リンゴジュース $200 \mathrm{ml})$ 摂取 30 分後

C) 高脂肪食 (30gm バタ一付トースト 2 枚・リ ンゴジュース $200 \mathrm{ml})$ 摂取 30 分後

D) 高脂肪食 (30gm バター付トースト 2 枚・リ ンゴジュース $200 \mathrm{ml}$ ) 摂取 3 時間後

採血はクアゼパム服薬前および服薬後 $1,2,3,4$, $5 ， 6 ， 8 ， 12 ， 24,48$ 時間後に施行した。精神運 動機能評価として DSST (Digit Symbol Substitution Test) および SSS (Stanford
Sleepiness Scale)を採血時に施行した。血漿蒋 物濃度測定はHPLCにて測定した。

\section{【結果】}

絶食時に比較し、低脂肪食服用 30 分後、高脂肪 食服用 30 分後、高脂肪食服用 3 時間後のクアゼ パムの最高血漿濃度 $\left(C_{\max }\right)$ はそれぞれ $243 \%$ 、 $272 \%$ および $249 \%$ あった。 (2)絶食時に比較し、8 時間までの血漿濃度時間 曲線下面積 (AUC (0-8)) および AUC (0-48) は低脂 肪食服用 30 分後 (1.9 倍、 1.4 倍) 、高脂肪食服 用 30 分後 (2.2 倍、 1.5 倍) 、高脂肪食服用 3 時間後 (2.1 倍、 1.5 倍)に有意に増加した。 (3)2-オキソクアゼパムの薬物動態は未変化体と 同様の変化を示した。

(4)食事後の薬物動態は 3 群間でクアゼパムにお いても 2-オキソクアゼパムにおいても差はなか った。

(5)統計学的に差は認めないものの、精神運動機 能パラメーター(DSST および SSS) は薬物動態の 変化に反応する傾向を示した。

\section{【結論】}

本研究では食事捸取後 3 時間までクアゼパムの 吸収に対する食事摂取の影響が明らかとなった。 睡眠導入薬を服用する生活習慣を考慮に入れれ ば、長時間の絶食後のクアゼパム服用は薬効が 十分に発揮されない可能性が示唆された。一方、 脂肪含有量は食事による薬物動態変化 $\left(\mathrm{C}_{\max } 2.5\right.$ 倍、AUC(0-8) 2.1 倍）の影響を与えなかった。 クアゼパムの忍容性の高さから、食事により投 与量の調節が必要とはならないと考えられた。

\footnotetext{
*1 弘前大学医学部臨床薬理学 干 036-8562 弘前市在府町 5

*2 弘前大学医学部神経精神科学
} 


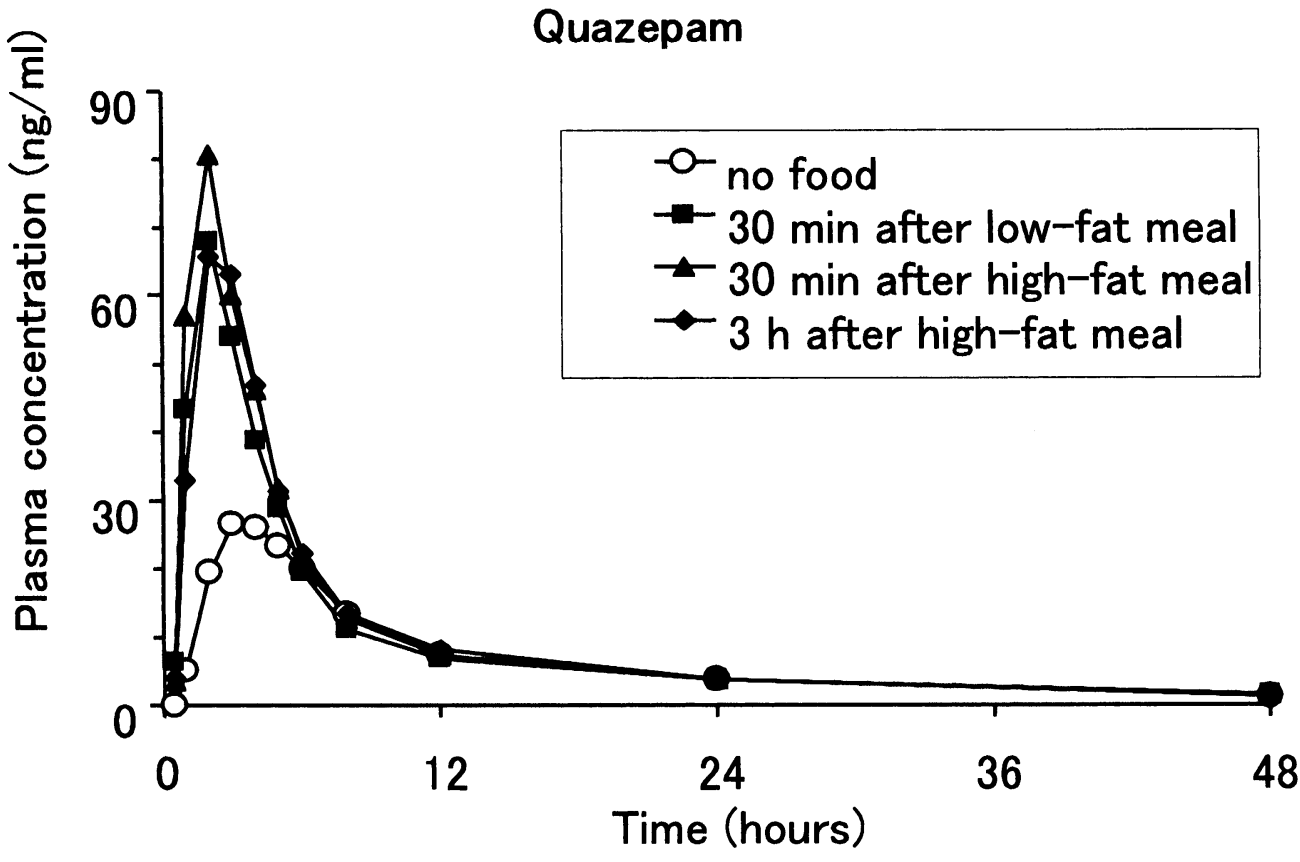

The mean plasma quazepam concentration-time curve from 0 to $48 \mathrm{~h}$ after a single oral dose of $20 \mathrm{mg}$ of quazepam. 